\title{
BEHIND THE CURTAIN OF PHYLOGENY: FROM THEATRICAL ANTHROPOCENTRISM TO INTERSPECIES APPRECIATION
}

JAN MOTAL

Theatre Faculty, Janáček Academy of Music and Performing Arts in Brno

\begin{abstract}
The theoretical essay discusses the horizontal (cultural) and the vertical (speciesism) dominance of theatre studies, i.e. its Eurocentrism and anthropocentrism. In the context of the global environmental crisis, the essay presents a critique of the field in question and suggests a benchmark of ecological relevance (Glen Love). The fallacies prevailing in theatre scholarship - especially those implicated by the current popularity of the concept of theatricality (Theatralität) and the usage of the term "theatre" to explain other cultures' phenomena - are shown, and the arguments for transgressing speciesism (Peter Singer) in theatre are presented (animal's mimesis, mirror neurons, theory of mind, zoosemiotics). Physiological faculties which make Homo sapiens able to perform and understand theatre are discussed in phylogenetic scope, and the interspecies continuity (homology, Ernst Haeckel) is presented as an unconscious archetypal heritage (Carl Gustav Jung, Anthony Stevens). The author argues that a revitalization of katharsis is necessary. The new formulation of the term based on interspecies empathy (Frans de Waal) should extend the boundaries of a community to include non-human individuals. The article concludes that theatre studies should contribute to the reintegration of humans to the wider environmental landscape. Possible ways how to achieve this are discussed.
\end{abstract}

Keywords: the environmental crisis, theatre theory, theatricality, speciesism, Eurocentrism, anthropocentrism, mirror neurons, mimicry, mimesis, katharsis, empathy

\section{Introduction}

The presented essay aims to outline the critique of theatre studies' foundations, which, in the following interpretation, are understood as ethnocentric and. The concept chosen for this deconstructive endeavor is to be the notion of theatricality (Theatralität), even though the term is hardly universally accepted. However, it allows us to grasp the suppressed ontological conditions of theatre studies. My critique arises from the present-day recognition of the overwhelming consequences of longstanding anthropocentrism and Eurocentrism of late modern knowledge. ${ }^{1}$ Despite the boastful

\footnotetext{
${ }^{1}$ Enrique Dussel, for example defines the Eurocentric paradigm as follows: "[...] modern subjectivity develops spatially, according to the Eurocentric paradigm, from the Italy of the Renaissance to the Germany of the Reformation and the Enlightenment, to the France of the French Revolution; throughout, Europe is central." Beyond Eurocentrism: The World-System and the Limits of Modernity. In JAMESON, F. - MIYOSHI, M. (Eds.). The Cultures of Globalization. Durham - London : Duke University Press, 1998, p. 4. This is in accord with the prevailing periodization of the history of theatre. The concept of theatre in the modern sense comes from Greek origins, rooted in the "classical" Athenian drama of $5^{\text {th }}$ Century BCE. As Dussel argues, "the unilineal diachrony Greece-Rome-Europe is an ideological construct that can be traced back to late-eighteenth-century German romanticism," and a conceptual by-product of the Eurocentric "Aryan model". The modern attitude follows Kantian "Ausgang" and postulates an ideal of rational "ego cogito".
} 
proclamations of postmodern theorists, there is hardly any apparent thoroughgoing shift even in the field of humanities.

While postcolonial thinking has dissolved some of the Eurocentric canons, many postmodern authors, by contrast, have contributed to the erosion of human awareness of broader environmental context. As the scholar of literature Glen Love shows, humanities in their anachronistic crusade against biological sciences have presented evolutionary approach as a mere "social construct", and therefore they have maintained the idea that "human behavior is [...] an empty vessel whose only input will be that provided by culture." I would like to join Love in claiming, "biological sciences are not just another cultural construction. Rather, they are the necessary basis for a joining of literature with what has proven itself to be our best human means for discovering how the world works." ${ }^{2}$

Vis-à-vis the global environmental catastrophe, it is evident that this community of academia Umwelt's inhabitants should include non-humans, who used to be excluded from humanities for a long time (and maybe it has always been so). In harmony with Glen Love's aim to revitalize literature studies, I would like to introduce the benchmark of ecological relevance to theatre studies: "In a real world of increasing ecological crisis and political decision making, to exclude nature except for its cultural determination or linguistic construction is also to accept the continuing degradation of a natural world that is most in need of active human recognition and engagement." 3

The ontological foundations ${ }^{4}$ of theatre studies as a form of modern scholarship can be criticized from various points of view. I adapt both horizontal and vertical approach. The former is to reveal the field's Eurocentric grounds (Greek theatre, modern European theatre), the latter shows that theatre scholars are misleadingly interpreting originally universal and the boundaries of human species transgressing phenomena (rituals, mimetic behavior, mirror neurons) as an evidence of specific theatricality, which is in consequence used as a justification of the field's importance.

\section{Eurocentrism}

In textbooks, e.g. in Brockett's History of the Theatre ${ }^{5}$, students read that theatre as a universal human phenomenon has its anthropological origins. It should be possible to trace rudimental forms of theatre in (almost) every culture - especially in its rituals. One of the vivid examples of this theatre prehistory for scholars and teach-

Instead of this myth, modernity is also a justification for an irrational praxis of violence. DUSSEL, E. Europe, Modernity, and Eurocentrism. In Nepantla: Views from South, 2000, Vol. 1.3, pp. 465 - 475. "The body of disciplinary knowledge [in social theory] is constituted by impregnable Western representations of self and others," remarks Siba N. Grovogui in Beyond Eurocentrism and Anarchy: Memories of International Order and Institutions. New York : Palgrave, 2006, p. 5.

${ }^{2}$ LOVE, G. A. Practical Ecocriticism: Literature, Biology, and the Environment. Charlottesville - London University of Virginia Press, 2003, pp. 6 and 8.

${ }^{3}$ SIKES, A. Theatre History, Theatrical Mimesis, and the Myth of the Abydos Passion Play. In Theatre History Studies, 2015, Vol. 34, p. 8. "The benchmark of ecological relevance" is a term coined by Glen Love.

${ }^{4}$ I.e. the field's primary definitional space, demarcating the terms of theatre, performance, theatricality, acting, drama, audience, play, meaning, scenic processes, and so on.

${ }^{5}$ BROCKETT, O. G. - HILDY, F. J. History of the Theatre. Harlow : Pearson, 2013, pp. 1 - 11 
ers usually is the "Abydos Passion Play" (occurred annually 2500-550 BCE). ${ }^{6}$ There is no dramatic text of this play available, and scholars rely only on an account left by an ancient Egyptian treasurer Ikhernofret, who was a witness of the celebration of Osiris, an Egyptian god. The academic effort to prove that the Abydos ritual was performed in a somehow theatrical way says more about theatre studies than about ancient Egyptian culture. It is overall anachronistic and Eurocentric. Analyzing ancient Egyptian concept of "heka" ("magic"), Alan Sikes proves that it is impossible to use modern semiotics and mimetic theory to understand Abydos rituals: "[...] the labelling of the Ikhernofret Stela event as a theatrical 'Passion Play' is an imposition of our own terminology onto practices ill-suited to receive it." ${ }^{7}$

For the argument of this article, this is a vivid example of the field's horizontal effort to dominate. It is horizontal because it uses a particular, modern European concept of theatre, as it was coined in the late $18^{\text {th }}$ Century, to understand and even explain other cultures' phenomena. If we would like to reintegrate theatre studies to the wider environmental landscape, we should start with shrinking the theatre empire, which has recently considerably expanded.

This imperial expansion of the research is overwhelming. After World War II, theatre scholars have discovered an entirely new field of interest - other cultures and public space (Theatralität). ${ }^{8}$ It is understandable that in accord with the postwar generation of activists, experimentalists and social prophets such as Jerzy Grotowski and Richard Schechner, theatre scholars recognized that the essentialism of their field of study is unmaintainable. ${ }^{9}$ In the 1970s and later, mainly German researches led by Joachim Fiebach, Rudolf Münz and Erika Fischer-Lichte aimed to perform the same shift, which was apparent in the theatre itself - to include everydayness, rituals and social life into their work. However, what can nurture artistic work can be risky in academia. Instead of deconstructing the ontological entitlements of theatre studies and elaborating their genealogy, the aforementioned scholars and their followers have extended the use of the concept of the theater (as theatricality) with all its withheld ontology. This endeavor is persistent to date.

In Czech theatre studies, we can observe a young, but a tenacious tradition of the "theatricality of public events". Public gatherings, religious celebrations, politi-

\footnotetext{
${ }^{6}$ Ibid., p. 7.

${ }^{7}$ SIKES, A. Theatre History, Theatrical Mimesis, and the Myth of the Abydos Passion Play, p. 13.

${ }^{8}$ For an overview of the concept of theatricality (Theatralität) see MUSILOVÁ, M. Teatralita veřejných událostí - uvedení do problematiky [Theatricality of public events - introduction]. In Theatralia, 2014, Vol. 17, Issue 1, pp. 9 - 24. For the examples of using the concept to colonize other culture's knowledge, see e.g. BALME, Christopher B. Sexual Spectacles: Theatricality and the Performance of Sex in Early Encounters in the Pacific. In The Drama Review, 2000, Vol. 44, Issue 4, pp. 67 - 85; FIEBACH, J. Dimensions of Theatricality in Africa. In Research in African Literatures, 1999, Vol. 30, Issue 4, pp. 186 - 201; or KRASBERG, U. Theateranthropologische Betrachtungen zum Ekstasetanz von Frauen in Marokko. In Anthropos, 2001, Vol. 96, Issue 2, pp. 379 - 390. Especially Ulrike Krasberg's article is a vivid example of the knowledge colonization. She uses Jerzy Grotowski to explain "dhikr" - religious dancing of Muslim women, who have never heard of Grotowski or his theatre. This application of a normative theatre theory is a form of discursive domination, which tries to understand a complex native phenomenon using an exclusive ethnocentric concept.

${ }^{9}$ In this essay, I disregard the differences between performance studies in Polish and German theatre studies' tradition. The former is more based on anthropology (e.g. Richard Schechner employing Victor Turner's theories); the latter uses the notion of Theatralität. The history of the regional fields of study, their genealogy, and theoretical problems differ greatly. For the sake of simplicity, I focus solely on the issues of the German concept.
} 
cal trials, or folk fairs are analyzed under the canopy of theatre studies. ${ }^{10}$ The aim of the researches is hardly to extend theatre theory. It is instead an attempt to expand its boundaries (and researchers' field of competence). The theatre scholars use their "native" methods and theories to putatively enrich the understanding of the welldescribed and frequently analyzed phenomena (by cultural anthropology, sociology, political marketing, religious studies, media studies and other). However, this enrichment is merely speculative. What is - or should be - a useful conceptual metaphor or figure ("costume", "scene", "gesture", or other) becomes an instrument for an explanation. It is obvious that a public event resembles theatre and any theatrical analysis can hardly transgress this apparent fact. On the contrary, it should rather be said that any theatre resembles a public event. It is barely plausible to use a narrow, historically and geographically determined phenomenon such as theatre to explain or interpret universal phenomena (which are hardly exclusively human, as the chimpanzee's "rain dance" suggests).

To conclude, the main argument against the use of theatricality to grasp anything else than theatre is that it reverses the relationship between the set and its elements. The set of social phenomena includes theatre as an institution originating in ancient Greece, adapted by European nations, developed by Elizabethan theatre and classical German dramaturgy leading to the concept of national theatre (and avant-gardes, afterwards). In the colonial era, this institution was recognized by Europeans even in other civilizations, no matter what "native" cultural function it had. Europeans have also influenced non-European theatre during those times. In retrospect, we can trace phenomena that resemble theater in the history of many cultures - and we can also find elements of theater outside of them. However, none of this gives theatre researchers the right to proclaim one cultural tradition as an interpretative framework for other traditions. The set of social phenomena cannot be entirely defined by its element ("theatre"), only if it is a synecdoche pars pro toto (as it is in Goffman's theory). It is, therefore, better to shift the question to "how to describe theatre as a social phenomenon", i.e., how to use a set to characterize one of its elements. Research into the relationship between theatre and other elements of the set (synchronously and diachronically) is a serious and important work, which unfortunately is still waiting for theater scientists. Understandably, scholars aim to avoid it - rather than to expand their holdings, they would have to extend the boundaries to foreign scientists, nations, and theories. Instead of colonialism, they would have to open borders and let defeated nations to go inland. Only then, we could learn to live together in our realm of "theatre."

${ }^{10}$ For examples of the "theatricality of public events" studies see e.g. DERIX, S. Facing as "Emotional Crunch": State visits as political performances during the cold war. In German Politics E Society, 2007, Vol. 25, Issue 2, pp. 117 - 139; JAKOVLJEVIĆ, B. Theater of Atrocities: Toward a Disreality Principle. In PMLA, 2009, Vol. 124, Issue 5, pp. 1813 - 1819; Chapter "Theatricality and the Public Realm" in VILLA, D. R. Politics, Philosophy, Terror: Essays on the Thought of Hannah Arendt. Princeton : Princeton University Press, 1999, pp. 128 - 154; Chapter "'War,' ,Terrorism,' and ,Spectacle': On Towers and Caves" in WEBER, S. Theatricality as Medium. New York : Fordham University, 2004, pp. 326 - 335; in Czech theatre studies e.g. JUST, V. Teatralita politického procesu aneb „Horáková a společníci“ jako divadelní inscenace [Theatricality of political trial, or "Horáková and fellows" as a theatre performance]. In Divadelní revue, 2006, Vol. 17, Issue 1, pp. 3 - 32; MUSILOVÁ, M. Teatralita veřejných událostí - uvedení do problematiky, pp. 9 - 24. 


\section{Anthropocentrism}

The critique of the horizontal dominance of theatre studies is hardly new, although now it slightly resembles the proverbial storm in a teacup than a serious attempt to audit the field's fundamental assumptions. To conclude that the term "theatre" (and its adjectives and substantive adjectives) should be used to label narrower (and culturally and historically limited) rather than wider group of phenomena is not enough to be environmentally relevant. It helps the field to reintegrate itself to the human landscape (i.e. to reduce its cultural ambitions). What we need now in the sense of ecocriticism is to take another step and reintegrate the study of theatre to broader non-human perspective - that is what I would call "to suspend field's vertical dominance."

It is evident, yet marginally reflected fact, that theatre scholarship is anthropocentric. ${ }^{11}$ At first sight, it seems to be counterintuitive to say that theatre studies should not be anthropocentric - who (or what) else than humans are performing theatre events? However, this vertical problem is analogous to the previously discussed horizontal one. Of course, dogs, chimpanzees or vervets do not play theatre. Just as we admit that ancient Egyptian rituals are not theatre, it cannot also be e.g. chimpanzee's "rain dance". However, the problem remains that the prevailing theatre ontology understands performative faculties of human species as something evolutionary exclusive. This exclusivity serves to justify the study of theatricality, itself putatively being a manifestation of human evolutionary dominance (as a paramount cultural phenomenon). But to say that theatre is human phenomenon sui generis (and has nothing at all to do with animals) means to contribute to the proliferation of division between nature and culture as it was described in Bruno Latour's blistering work. ${ }^{12}$

Una Chaundri calls for the revision of the anthropocentric fundamentals of the field: "Embodiment, presence, process, event, force: these performative themes of contemporary zoonotology invite a recollection of theatre's roots in zoomorphic cults and theriomorphic rituals and of the animalizations of classical and folk performance forms around the world."13

In fabulae saturae, Attelan farces, Kalarippayatt or Teyyam in Kerala, Korean Narye Agamben humans imitated goats, wolves or Shibishen (the twelve animals of the Chinese calendar), performed animal postures, and so on. ${ }^{14}$ These performances are hardly "theatre" in the modern sense; their social functions and form were different.

${ }^{11}$ For the current critique of theatre anthropocentrism see e.g. ARONS, W. Theatre Ecology / Contemporary Plays. In Theatre Journal, 2007, Vol. 64, Issue 4, pp. 565 - 582; CHAUNDRI, U. “Of All Nonsensical Things": Performance and Animal Life. In PMLA, 2009, Vol. 124, Issue 2, pp. 520 - 525; ESTOK, S. C. Theory from the Fringes: Animals, Ecocriticism, Shakespeare. In Mosaic: An Interdisciplinary Critical Journal, 2007, Vol. 40, Issue 1, pp. 61 - 78; PETERSON, M. The Animal Apparatus: From a Theory of Animal Acting to an Ethics of Animals Act. In The Drama Review, 2007, Vol. 51, Issue 1, pp. 11 - 22; PUCHNER, M. Performing the Open: Actors, Animals, Philosophers. In The Drama Review, 2007, Vol. 51, Issue 1, pp. 21 - 32; RIDOUT, N. Stage Fright, Animals, and Other Theatrical Problems. Cambridge : Cambridge University Press, 2009; a special issue of Performance Research on animals, edited by Alan Read (2000, Vol. 5, Issue 2). Most of the scholars focus on particular performances or plays as well as on the problem of animals on stage. The more profound critique of theatre's anthropocentric ontology is still on the fringe.

${ }^{12}$ See LATOUR, B. We Have Never Been Modern. Cambridge, MA : Harvard University Press, 1993.

${ }^{13}$ CHAUNDRI, U. “Of All Nonsensical Things", p. 521.

${ }^{14}$ PRADIER, J.-M. Animals, Angel and Performance. In Performance Research, 2000, Vol. 5, Issue 2, p. 14. 
We can say that they are homologous to the European theatre because they employed dancing, acting, or wearing costumes. It means that the oldest human performances were not separated from nature, rather that they were part of it. They aimed to reintegrate humans into the ecosystem, not to manifest their exclusivity and dominance: "Present in ritual and festive forms of expression since time immemorial, animals were integral in the evolution of performance practices-and above all dance-right up until the cultural and social separation of species consigned them to rural milieus of a traditional kind."15

To reintegrate humans back to their environmental landscape requires avoiding presenting the universal faculties (such as mimesis, as I would like to argue later) as species exclusive. They are somewhat archetypal in the sense of species homology every actor, every audience member employs in their endeavor similar (but hardly the same) physiological and mental processes to their non-human fellows.

Anthropocentrism affirms human's exclusion from nature. From Darwin onward, we should understand every human individual as a part of the measureless evolutionary path. "It makes no more sense (and no less) to aim our historical narrative towards Homo sapiens than towards any other modern species - Octopus vulgaris, say, or Panthera leo or Sequoia sempervirens," Richard Dawkins pointedly remarks. ${ }^{16}$ We should hardly see mirror neurons as an exclusive instrument of theatre mimesis. There is no necessity for the theatre phenomenon; it is hardly a goal (even partial) of evolution to make humans be able to play theatre. Mirror neurons do not "want" to play theatre - they serve other functions. Fortunately, they are prepared to play theatre, when a specific human culture wants to perform a piece. Therefore, we should see theatre performance rather as an event in which non-theatrical faculties are involved, and what more - they are interspecies. Theatre is archetypal in the sense that it involves phylogenetic memory of our species, not only that it represents mythical archetypes. That is how Ernst Haeckel has described the law of homology in nature.

\subsection{From homology to archetype}

Haeckel formulated his concept of an archetype (he uses the term "Ur-Typus"17) during his study of Radiolaria and especially Heliosphaerea, which he identified as comparable to the Ur-type of the phylum - "[...] he hypothesized that this kind of organism was the archetype whence all of the fifteen families might be derived," proposing an idea, that "descent relationships might operate according to various mathematical deformations of the basic sphere."18 In his work and especially in his breathtaking illustrations, Haeckel produced representations of standard organisms, based on his experience with particular examples and judgment, with archetypes created by scientist's mind.

\footnotetext{
${ }^{15}$ Ibid., p. 13.

${ }^{16}$ DAWKINS, R. - WONG, Y. The Ancestor's Tale: A Pilgrimage to the Dawn of Life. London : Weidenfeld \& Nicolson, 2017, p. 6.

${ }^{17}$ HAECKEL, E. Die Radiolarien (Rhizopoda radiaria). Berlin : Georg Reimer, 1862, p. 233.

${ }^{18}$ RICHARDS, R. J. The Tragic Sense of Life: Ernst Haeckel and the Struggle over Evolutionary Thought. Chicago - London : The University of Chicago Press, 2008, p. 74. As Richards argues, Haeckel's definition of archetype was influenced by Goethean tradition of morphology.
} 
It was Haeckel's monism, abandoning mind-body dualism (in favour of nature), which "exerted a profound influence" on a group of intellectuals, like D. H. Lawrence, Herman Hesse or C. G. Jung, visiting Asconia on the Swiss shore of Lake Maggiore, where they were dwelling at "Monte Verita", the "mountain of truth" ${ }^{19}$ Unfortunately, any influence on theatre theory is marginal. Only theatre practitioners like Rudolf Laban or Isadora Duncan (both of them dancers) were convinced by this evolutionary deconstruction of anthropocentrism. Nevertheless, even they were far from recognizing humanity as a part of a wider ecosystem and they did not knock their art off the pedestal (even though Duncan refused to label herself "dancer"). For instance, for Duncan dance was an instrument of social betterment and progress to a higher level of development, not transgressing human boundaries to the ecosystem. ${ }^{20}$

How can we conceptually grasp the phenomenon of homology and be able to understand interspecies continuity? I propose to employ a theory of collective unconscious (das kollektive Unbewusstes), as the term was coined by C. G. Jung. Jung was influenced by the biological concepts of homology and evolutional archetype, and he elaborated on Freud's notion of the unconscious. Freud already conceived the term in accord with phylogeny: "The content of the Ucs. [unconscious] may be compared with an aboriginal population in the mind. If inherited mental formations exist in the human being-something analogous to instinct in animals-these constitute the nucleus of Ucs." 21

For Freud, the unconscious content is physiological, consisting of "instinctual representatives which seek to discharge their cathexis; that is to say, it consists of wishful impulses." ${ }^{22}$ Jung overcame Freudian reductionism (which limited the collective heritage to instincts) and extended the image of the unconscious to the archetypal landscape. For Jung, the unconscious has gradually detached from instincts in human evolutionary history, but it still retained its instinctual character. Modern humans have lost the connection with this inner nature and have succumbed to the myth of autonomy of ratio. However, from the Jungian point of view, autonomous are archetypes, not conscious rationality. ${ }^{23}$

As psychiatrist Anthony Stevens argues, the unconscious has its physiological base. The "archetypal memory" is inherited in the biological sense of meaning - archetypes are units of the natural mind. ${ }^{24}$ An archetype is not an idea, but for Stevens, it is "a pattern of behavior", the inherited experience of species, which transcends the "nature-versus-nurture" debate and heals "the Cartesian split between body and mind". ${ }^{25}$ What Stevens labels "the Paleolithic inner world" is the human phylogenetic link to ancestors, which binds all the nature to form one community on the basis of (certainly differentiated) homology. This is not only a philosophical assumption - it implies serious consequences in psychology. The "cultural" (higher, cognitive and creative processes especially in the neocortex) and "natural" human self is intercon-

\footnotetext{
${ }^{19}$ PRADIER, J.-M. Animals, Angel and Performance, p. 16.

${ }^{20}$ DALY, A. Isadora Duncan's Dance Theory. In Dance Research Journal, 1994, Vol. 26, Issue 2, pp. 25 - 26.

${ }^{21}$ FREUD, S. The Unconscious [1915]. In FREUD, A. (ed.) The Essentials of Psycho-analysis. London : Vintage Books, 2005, p. 166.

${ }^{22}$ Ibid., p. 159.

${ }^{23}$ JUNG, C. G. - FRANZ, M.-L. et al. Der Mensch und seine Symbole. Olten : Walter-Verlag, 1968, p. 83.

${ }^{24}$ STEVENS, A. The Two Million-Year-Old Self. Texas : A\&M University Press, 2005, p. 10.

${ }^{25}$ Ibid., pp. $9-13$.
} 
nected, as Antonio Damasio shows: "The hypothalamus, the brain stem, and the limbic system intervene in body regulation and in all neural processes on which mind phenomena are based, for example, perception, learning, recall, emotion and feeling, and $[\ldots]$ reasoning and creativity. Body regulation, survival, and mind are intimately interwoven." 26

The research ${ }^{27}$ proves that archetypes should be understood as our phylogenetic memory imprinted on biological tissue using chemical and electrical signal pathways and ancient parts of the human body (especially the "reptilian" and "paleomammalian" complexes of the brain). Current neuroscience supports these assumptions with the developing research on the transgenerational transmission of trauma implying that some experiences (such as PTSD) can be epigenetically inherited - transforming individual unconscious into the collective (or shared, at least). ${ }^{28}$ The multigenerational transmission of ancestral phenotypic responses is documented even on plants and animals. ${ }^{29}$

\section{Animal mimesis}

When an ethologist Jane Goodall has seen the chimpanzee's "rain dance" ${ }^{\text {"30 }}$ for the first time, she was amazed. It has been splendid to watch animals to perform a ritual, and Goodall was furthermore lucky to see chimpanzees to perform collectively, which is even rarer. "The actor taking his final curtain," she wrote later in the final sentence of the ritual's description. ${ }^{31}$ These words - performance, actor, curtain, ritual - are startling when used in the context of animal behavior. Yet, they are hardly mere noble metaphors. In the animal realm, we surely can find faculties, which are homologous to human mimesis. ${ }^{32}$

\section{1 "Acting" animals}

The prevalent animal form of "acting" is mimicry, which is not limited to mere changing of skin colours, for example displaying of eyespots. Mimicry usually in-

${ }^{26}$ DAMASIO, A. Descartes' Error: Emotion, Reason and the Human Brain. London : Vintage Books, 2006, p. 123.

${ }^{27}$ For contemporary discussion on scientific arguments on Jungian psychology see e.g. GOODWYN, E. Approaching archetypes: reconsidering innateness. In The Journal of Analytical Psychology, 2010, Vol. 55, Issue 4, pp. 502 - 521; or HUNT, H. T. A collective unconscious reconsidered: Jung's archetypal imagination in the light of contemporary psychology and social science. In The Journal of Analytical Psychology, 2012, Vol. 57, Issue 1, pp. 76 - 98; For more complex approach see GOODWYN, E. The Neurobiology of the Gods. New York : Routledge, 2012.

${ }^{28}$ KELLERMANN, N. P. F. Epigenetic Transmission of Holocaust Trauma: Can Nightmares Be Inherited? In Israel Journal of Psychiatry and Related Sciences, 2013, Vol. 50, No. 1, pp. 33 - 39.

${ }^{29}$ JABLONKA, E. - RAZ, G. Transgenerational epigenetic inheritance: prevalence, mechanisms, and implications for the study of heredity and evolution. In The Quarterly Review of Biology, 2009, Vol. 84, No. 2, pp. 131 - 176; SZYF, M. Nongenetic inheritance and transgenerational epigenetics. In Trends in Molecular Medicine, 2015, Vol. 21, No. 2, pp. $134-144$.

${ }^{30}$ SEBEOK, T. A. Prefigurements of Art. In MARAN, T. - MARTINELLI, D. - TUROVSKI, A. (eds.) Readings in Zoosemiotics. Berlin - Boston : De Gruyter, 2011, p. 206.

${ }^{31}$ GOODALL, J. In the Shadow of Man. London : Phoenix, 1999, p. 52.

${ }^{32}$ For more elaborative argument and evidence on the topic of primate dance see FRANCIS, S. T. The origins of dance: The perspective of primate evolution. In Dance chronicle, 1991, Vol. 14, Issue 2 - 3, p. 207. 
volves resembling of other animals' markings or even behavior, as David McFarland shows. For instance, coral snake Lampropeltis elapsoides mimics the colors of poisonous Micrurus fulvius, some snakes of the genus Dasypeltis perform the warning display of the African carpet viper Echis carinata producing specific noise, "some hole-nesting birds hiss like a snake if disturbed on the nest." 33 This form of deceit is of evolutionary importance, being a form of defence against predators. For our cogitations, it is important to admit, that even if this behavior is not conscious in the sense of human's free will and we say that it is instinctive, it shows that the performance of imitation is not exclusive to humans. To imitate, i.e., to act like other being and try to persuade spectator that the imitator is another being ("illusiveness"), is prevalent in nature. Aristotle's famous claim from Poetics that humans have "a natural instinct for representation [mimesthai]" 34 should be amended - "an instinct for representation is prevalent in nature."

Animal's mimicry is a form of communication using visual, acoustic and gestic signs - the very same resources of actor's work (the animal communication is studied by zoosemiotics, a science established by Thomas A. Sebeok in the 1960s). What is more remarkable is that mimicry can even serve as a communication among species. For example, the trumpetfish Aulostomus uses camouflage to infiltrate schools of yellow sturgeon - this strategy is called commensalism. ${ }^{35}$ Other examples of this animal "acting" involve dogs' tooth-baring or male-female communication in the situation of possible reproduction.

All of these are examples of ritualized behavior, which is aimed to gain an advantage for the "acting" animal. The principle is still the same - there is an animal, which imitates other's behavior or uses visual, acoustic or gestic signs to present a threat or a demand to another animal ("spectator"). Even if this behavior is not voluntary, it involves all that is familiar for those who deal with theatricality - costumes, gestures, makeup, sound effects, even dancing (e.g. animal courting). Intra- and intersexual choice of mates in nature involves a lot of this "acting", and not only in the case of attracting females. "Male rivalry involves ritualized combat, bluff, assessment of the rival's fighting potential," and this rarely leads to real fighting. ${ }^{36}$ Animals are performing a great "theatre" for their companions and potential mates. Their art of mimesis has to be superior to professional human actors, because unlike for people, it is survival what is at stake for the animals.

\subsection{Symbolic play versus make-believe}

The difference between human and animal mimesis seems to be in a difference between true symbolic play and feature-dependent make-believe, as Jesse M. Bering claims. Bering argued that humans are able to represent objects, scripts and mental events "in the absence of any perceptual eliciting stimuli", whereas other animals in

\footnotetext{
${ }^{33}$ MCFARLAND, D. Animal Behavior: Psychobiology, Ethology and Evolution. Menlo Park : The Benjamin/ Cummings Publishing Company, 1985, pp. $406-407$.

${ }^{34}$ ARISTOTLE. Poetics 1448b20. Quoted translation by FYFE, W. H., Vol. 23 of Aristotle's work, Cambridge - London : Harvard University Press - William Heinemann, 1932.

${ }_{35}^{35}$ MCFARLAND, D. Animal Behavior: Psychobiology, Ethology and Evolution, p. 408.

${ }^{36}$ Ibid., p. 126.
} 
their imaginative plays do not involve "a clear detachment from the perceptual cues of the incorporated objects." ${ }^{37}$

Research shows that this division is not only between Homo sapiens and the rest of the animal realm. Judy A. Ungerer with her colleagues investigated developmental differences in the way children impersonated objects and found that children between $18-34$ months of age are using feature-dependent make-believe rather than symbolic play. ${ }^{38}$ Therefore, we cannot say that the "symbolic divide" lies between humans and animals. This assumption is untenable.

Concerning Peter Singer's theory of speciesism ${ }^{39}$, it is barely possible to claim the superior status of humans based on their cognitive abilities. What about little children, who are not able to understand language, play symbolically, perform abstract thinking? What about people with psychic disabilities, who are not even capable of speech or rational argument? Does it mean that they are not Homo sapiens in the proper sense (from the biological point of view that is hardly true)?

Not at all - that only proves we should not define our position in nature on the basis of the finest skills we possess. Moreover, we cannot say that theatre is typical for humans when most of us do not attend theatre regularly, and only a fraction of Homo sapiens watch non-commercial, artistic performances theatre scholars consider valuable.

Therefore, we should adjust our assertion. There is not a difference between human and non-human mimesis, but between mimesis of those with higher cognitive abilities and those without them. This implies very serious inferences: a) we should refuse the assumption that any theatre performance is (inherently) accessible to a general audience because it excludes people with cognitive disabilities, $b$ ) the ability to understand theatre as symbolic play should not define humanity. Non-symbolic forms of theatre, i.e. certain types of dance and performances involving feature-dependent make-believe could be (presumably) accessible even to a non-human audience. ${ }^{40}$

\subsection{Mirror neurons and empathy}

Thanks to Erika Fischer-Lichte's remark in her Ästhetik des Performativen ${ }^{41}$, mirror neurons have recently become a huge hype in the field of theatre studies. ${ }^{42}$ Contrary

\footnotetext{
${ }^{37}$ BERING, J. M. Theistic Percepts in Other Species: Can Chimpanzees Represent the Minds of NonNatural Agents? In Journal of Cognition and Culture, 2001, Vol. 1, Issue 2, p. 119.

${ }^{38}$ UNGERER, J. A. - ZELAZO, P. R. - KEARSLEY, R. B. \& O'LEARY K. Developmental Changes in the Representation of Objects in Symbolic Play from 18 to 34 Months of Age. In Child Development, 1981, Vol. 52, pp. $186-195$.

${ }^{39}$ SINGER, P. Speciesism and moral status. In Metaphilosophy, 2009, Vol. 40, Issue 3 - 4, pp. 572 - 573. The following argument to a certain degree corresponds with Peter Singer's.

${ }^{40}$ This is only a hypothesis, of course. Its accurateness is to be proved by experimental methods (if that is possible at all).

${ }^{41}$ Fischer-Lichte links mirror neurons to Max Herrmann's observation of reciprocal audience interaction. See FISCHER-LICHTE, E. The Transformative Power of Performance: A New Aesthetics. London - New York : Routledge, 2008, p. 36, footnote 12.

42 The overview of the literature is beyond the scope of this article. For a brief orientation, see these examples from diverse fields: COOK, A. Interplay: The Method and Potential of a Cognitive Scientific Approach to Theatre. In Theatre Journal, 2007, Vol. 59, Issue 4, pp. 579 - 594; JOLA, C. - POLLICK, F. E. - GROSBRAS, M. H. Arousal Decrease in Sleeping Beauty: Audiences' Neurophysiological Correlates to Watching a Narrative Dance Performance of two-and-a-half hours. In Dance Research, 2011, Vol. 29, pp. 378 - 403;
} 
to the general opinion, the neurobiological evidence gives hardly any hope for theatre scholars that on the neuronal level we can recognize any specifically theatrical mental processes. Quite the reverse, the available research (although being fragmentary) shows that the existence of "mimetic" neurons documents interspecies nature of mimesis and proves its evolutional significance as one of the underlying mechanisms of understanding others' behavior. It underlines our assumption that theatre is only one culturally determined form of universal behavior transgressing the boundaries of species.

Mirror neurons are "inherently 'multimodal' as they respond to more than one modality ${ }^{\prime 43}$, meaning that the firing of a single neuron involves the action-concept recognition in the brain (parietal-premotor networks). This assumption is coherent even with the findings of experiments with animal's F5 brain area conducted by Rizzolatti and his coworkers. Most of the examined neurons discharged "in association with goal-directed actions, such as grasping, manipulating, tearing, holding" and the researchers claim that the mirror neurons are not involved in mere imitation but action understanding. ${ }^{44}$ Other scholars provide evidence that mirror neurons (in area 7B, monkey Macaca fuscata inferior parietal cortex) respond differentially to identical actions embedded in different contexts and this can be understood as to be a component of protolanguage coding mechanism in the ancestral primate brains. ${ }^{45}$ Experiments with ventral premotor cortex mirror neurons of Macaca nemestrina showed that the mirror neurons were active even when the action was not in monkey's full vision. ${ }^{46}$ This study supports the hypothesis that the neurons serve action recognition because animals had to infer the goal of the action.

In the human brain, there are areas corresponding to monkey cortical areas with the recorded activity of mirror neurons - the left superior temporal sulcus (STS), the left rostral part of the inferior parietal lobule (area 40) and the left interior frontal cortex (area 45). ${ }^{47}$ The latter, together with area 44, forms Broca area being responsible for semantic tasks and control of the production of intelligible speech. It lies near the region of the motor area responsible for mouth and tongue movements. ${ }^{48}$ There is experimental evidence that left inferior frontal gyrus (where BA45 lies) enables the selection of relevant information from competing semantic knowledge. ${ }^{49}$ As Tsujii et

MEINECK, P. The Neuroscience of the Tragic Mask. In Arion: A Journal of Humanities and the Classics, 2011, Vol. 19, Issue 1, pp. $113-158$. The Theatre Journal dedicated its volume 59 to neuroscience; the Dance Research volume 29 focuses on the same topic.

${ }^{43}$ GALLESE, V. - LAKOFF, G. The Brain's Concepts: The Role of the Sensory-Motor System in Conceptual Knowledge. In Cognitive Neuropsychology, 2005, Vol. 22, Issue 3 - 4, p. 458.

${ }^{44}$ RIZZOLATTI, G. - FADIGA, L. - FOGASSI, L. - GALLESE, V. Resonance Behaviors and Mirror Neurons. In Archives Italiennes de Biologie, 1999, Vol. 137, pp. 85 and 94.

${ }^{45}$ YAMAZAKI, Y. - YOKOCHI, H. - TANAKA, M. - OKANOYA, K. - IRIKI, A. Potential role of monkey inferior parietal neurons coding action semantic equivalences as precursors of parts of speech. In Social Neuroscience, 2010, Vol. 5, Issue 1, pp. $105-117$.

${ }^{46}$ UMILTÀ M. A. - KOHLER, E. - GALLESE, V. - FOGASSI, L. - FADIGA, L. - KEYSERS, C. - RIZZOLATTI, G. I Know What You Are Doing: A Neurophysiological Study. In Neuron, 2001, Vol. 31, Issue 1, pp. $155-165$.

${ }^{47}$ RIZZOLATTI, G. - FADIGA, L. - FOGASSI, L. \& GALLESE, V. Resonance Behaviors and Mirror Neurons, p. 95.

${ }^{48}$ KANDEL, E. R. - SCHWARTZ, J. H. - JESSELL, T. M. - SIEGELBAUM, S. A. - HUDSPETH, A. J. Principles of Neural Science. Fifth Edition. New York : McGraw-Hill, 2013, p. 11.

${ }^{49}$ THOMPSON-SCHILL, S. L. - D'ESPOSITO, M. - KAN, I. P. Effects of Repetition and Competition on Activity in Left Prefrontal Cortex during Word Generation. In Neuron, 1999, Vol. 23, p. 519. 
al. ${ }^{50}$ showed, the inferior frontal cortex (IFC) also plays a role in belief-bias reasoning, when stimulation of the left IFC eliminated the belief-bias effect making subjects not suffer from interference by irrelevant semantic processing.

The STS is presumably an important factor in social perception, because it is possible that "over the course of evolution and development, the multisensory anatomy of the STS has been recruited for social processes, such as theory of mind, that make use of information from multiple modalities." ${ }^{51}$ Especially in social neuroscience and developmental psychology, there is fruitful research on the theory of mind (ToM) available up to date..$^{52}$ The term was coined in 1978 by David Premack and Guy Woodruff in order to describe a system of inferences, which an individual employs to impute mental states to himself and others. The researchers proved that even chimpanzees could recognize actions on a videotape as representing a problem, they could understand the actor's purpose, and choose alternatives compatible with that purpose..$^{53}$ The fact that there are mirror neurons present in STS implies that the neurons play a role in this understanding of other's actions. The ToM concept provides a plausible explanation of the mirror neuron's function. Rather than to "copy" behavior, it seems that they serve to help animals to experience mental states of others: "What makes the neurons special is the lack of distinction between 'monkey see' and 'monkey do.' They erase the line between self and other, and offer a first hint of how the brain helps an organism mirror the emotions and behavior of those around it."54

As Frans de Waal argues, this identification "opens the door for empathy", leading even to the refusal of the popular philosophical (and entirely fallacious) Hobbesian idea of the natural state being bellum omnium contra omnes. What scholars of theatre see as a condition of theatricality is from a more comprehensive, phylogenetic point of view the physiological ground of empathy and bonding.

The concept of theatricality involves a presumption that in human society a specific "theatrical" behavior exists and the analysis of this kind of behavior can help to explain other phenomena (such as are religious rituals, political gatherings or trials). My argument is that we should reverse our point of view and see theatre as a phenomenon explainable by other concepts and theories (transgressing the field boundaries). The specific theatre mimetic behavior (involving professional actors and audience) should be understood as an instance of mental strategies and cognitive faculties, which makes us able to live in a community. This notion of a community should not be only human, as I would like to conclude later. For this conclusion, I have to provide a brief revision of the notion of katharsis, enabling me to show how the non-anthropocentric and non-ethnocentric theatre studies can contribute to solving our prevailing environmental crisis - and reach its political importance.

${ }^{50}$ TSUJII, T. - MASUDA, S. - AKIYAMA, T. - WATANABE, S. The Role of Inferior Frontal Cortex in Belief-bias Reasoning: An rTMS Study. In Neuropsychologia, 2010, Vol. 48, Issue 7, pp. 2005 - 2008.

${ }^{51}$ BEAUCHAMP, M. S. The Social Mysteries of the Superior Temporal Sulcus. In Trends in Cognitive Sciences, 2015, Vol. 19, Issue 9, p. 490.

${ }^{52}$ See e.g. MAHY, C. E. V. - MOSES, L. J. - PFEIFER, J. H. How and Where: Theory-of-mind in the Brain. In Developmental Cognitive Neuroscience, 2014, Vol. 9, pp. 68 - 81.

${ }^{53}$ PREMACK, D. - WOODRUFF, G. Does the chimpanzee have a theory of mind? In The Behavioral and Brain Sciences, 1978, Vol. 4, pp. $515-526$.

${ }^{54}$ WAAL, F. The Age of Empathy: Nature's Lessons for a Kinder Society. New York: Three Rivers Press, 2009, p. 79. See also RIZZOLATTI, G. - SINIGAGLIA, C. Mirrors in the Brain-How Our Minds Share Actions and Emotions. Oxford : Oxford University Press, 2008. 


\section{Katharsis Pruning Rather than Purifying}

Katharsis is maybe one of the most proliferated terms in modern aesthetics, although we have only partial evidence of what it meant for Aristotle. The philosopher uses the term katharsis only in his Politics, where he promises explanation in his study of poetry, and in Poetics, where we can read that it is an effect of experiencing pity and fear while watching the tragedy. ${ }^{55}$ An extensive tradition of interpretation is based on these incomplete and inadequate remarks of "the Philosopher", usually ignoring that Aristotle mentioned the term not only in relation to tragedy, but to music as well - making rhythm and melody important generators of katharsis: ${ }^{56}$ "[F]orm conferred upon the matter of emotional experience stirs, excites, carries the soul along; and then-because it is form-it gratifies, satisfies, purges away unhealthy perturbation, induces peace at the last, leaving the soul uplifted and serene." 57

It is useful to employ the broader philosophical context in the interpretation of the term, and I do not mean to quote only Plato, who blamed art rather than praised. For example, James Highland used the work of one of Aristotle's students, Theophrastus of Eresus, to interpret katharsis - on the basis of Theophrastus' botanical works. Highland not only shows that katharsis in Aristotelian tradition can hardly be reduced to an ethical or medical purification, but that katharsis has a biological context. Theophrastus used the term when referring to pruning, proper transforming a tree's nature. This kind of "therapia" (training) effects "physis" (nature) of the tree, guiding "the food that rises from the roots of trees to nourish them and promote the growth of fruit." ${ }^{58}$ Katharsis is therefore used not in a mere ethical, but in a developmental sense of meaning - it helps nature to be fructiferous (or, as Highland implies, to live according to nature).

As W. F. Trench claims, in Aristotle's aesthetics the aim of katharsis is eudaimonia, the well-being. Theophrastus' work shows a wider biological sense of the meaning. If we recognize emotions and empathy as faculties transgressing humanity, shared with (at least some) animals, ${ }^{59}$ we should reformulate this anthropocentric goal. The healing effect should not lead only to integration of human into society and achieving happiness, it has to re-integrate Homo sapiens back into a wider ecosystem, liberating his mind from "pure reason", making him again able to use and cultivate his "primordial" heritage (emotions, instincts) to flourish, understand him or herself as a part of nature (being an animal), and cooperate with other living beings.

The reductionist, anthropocentric interpretation of katharsis roots in Renaissance moralistic criticism, which used Aristotle's aesthetics as an instrument for a disciplination of human according to the mind-body dualism. This modern preference of reason diminishes emotions, instincts, and drives: "Renaissance critics were consistently moralistic, never approached aesthetics without relating it very closely to

\footnotetext{
${ }^{55}$ ARISTOTLE. Poetics, 1449b28. For English reference see the footnote No. 25.

56 "Pity and fear are resolved, through the melodic, harmonic rendering of them in terms of form, into peace at the last." TRENCH, W. F. The place of katharsis in Aristotle's aesthetics. In Hermathena, 1938, Vol. 26, Issue 51, pp. 125 - 126, quotation p. 130.

${ }^{57}$ Ibid., p. 123.

${ }^{58}$ HIGHLAND, J. Transformative Katharsis: The Significance of Theophrastus' Botanical Works for Interpretations of Dramatic Catharsis. In The Journal of Aesthetics and Art Criticism, 2005, Vol. 63, Issue 2, p. 158.

${ }^{59}$ See WAAL, F. The Age of Empathy.
} 
ethics, and felt sure that Aristotle was with them in this. But their own ethical outlook was deplorable, inhuman, in a most important respect, and they were far astray in thinking they had Aristotle with them in it. I charge with inhumanity leading scholars of the sixteenth century whose views went on permeating culture far beyond that century. They held that the philosopher could promulgate without blame, that the passions were diseases of the soul!" 60

I agree with W. F. Trench that it is definitely time to abandon the outdated Lessing's, Bernays' and Bywater's moralism ${ }^{61}$ and admit that human unconscious (and his or her emotions, even the collective ones) is not to be purged in katharsis, but should brighten up. ${ }^{62}$ In order to be a fructiferous and cooperative part of nature, human beings have to immerse in their collective unconscious. In theatre katharsis, it is possible because the form of artwork (rhythm, melody) prevents spectator to fall into unconsciousness and rather than to suppress his or her reason, it reintegrates it with psyche's subbase - the unconscious. Therefore, theatre can train humans in empathy not only towards the individuals of their own species but even beyond its frontiers.

\section{Conclusion}

Employing the benchmark of ecological relevance, how can theatre studies contribute to the environmental healing process? Hardly by using its anthropo- and Eurocentric anachronisms and proliferating their deficiencies to the other regions of culture and society than the theatre itself. The presented examples of interspecies homology are only partial and hardly represent a compact picture. Moreover, theatre scholars should not want to be biologists. They understand theatre and theatre is their field of expertise. It should remain as it is. However, we can use our own concepts to transgress reductionism of humanities and promote artistic contribution to the environmental healing process.

For me, the key concept is katharsis. I profess that we need the reevaluation of katharsis in theatre theory, being more ecological. We should be better disciples of Aristotle and Theophrastus, both being the first philosophers investigating an organism as a part of the environment. ${ }^{63}$ Both plants and animals (and human beings) flourish in "oikeios topos", the habitat, which can become home. Late modernity prefers economy - but we should rather understand ourselves in ecological terms. Maybe it seems to be inconceivable, but I believe that properly transformed theatre theory can contribute to the process of ecological "therapia" and a) show that even in "noble" artistic forms we are first and foremost animals (and part of nature); and b) teach us how to use the (shared) faculties to achieve interspecies understanding.

For theatre and performance studies, the building of community usually mean humans engaged in a performative event - such as it was in the case of Dionysus in 69

${ }^{60}$ TRENCH, W. F. The place of katharsis in Aristotle's aesthetics, p. 128.

${ }^{61}$ For more plausible interpretation of Aristotle's aesthetics see e.g. Richard Janko's translation of Aristotle's Poetics and attached commentary - JANKO, R. (transl.). Aristotle Poetics. Indianapolis - Cambridge : Hackett Publishing Company, 1987.

${ }^{62}$ TRENCH, W. F. The place of katharsis in Aristotle's aesthetics, p. 133. Trench does not speak about the unconscious but emotions. I understand emotions to be a part of the unconscious in the sense of the aforementioned theories (especially A. Damasio).

${ }^{63}$ HUGHES, D. J. Theophrastus as Ecologist. In Environmental Review: ER, 1985, Vol. 9, Issue 4, p. 296. 
by Richard Schechner's The Performance Group. This point of view exploits the anthropological theory of ritual (especially Victor Turner's concepts) and tries to resuscitate mythical "lost theatre", forgotten by modern humans. Of course, every theatrical event forms a kind of community - no matter whether it was the leftist Theatre of the Oppressed or theatre in the Third Reich. It is because theatre involves faculties, which makes individuals experience others' mental states and sees them behave like themselves. When we dive into our inner depth (phylogenetic memory), when we admit that these faculties are to some degree shared, we can understand ourselves as a part of long phylogenetic history and reintegrate ourselves into the environmental landscape. Theatre studies should transgress the narrow interpretation of what the community means and show how theatre engages the non-human ground of humans. It requires the scholars to abandon concepts such as theatricality and listen to biologists, neuroscientists, and ethologists, who can provide a broader perspective. Our aim as scholars in humanities is to inform artists, audiences, and critics that in every theatre event, humans reach to their evolutionary heritage, instead of proving themselves to be masters of creation.

The question of the day is: how our "topos" can be "oikeios", better inhabitable, for all beings living in it? ${ }^{64}$ This appeal aims not only to artists but to researchers as well. I believe that we are obliged to provide plausible evidence and theories that can explain theatre not as an instrument of dominance (cultural, speciesism), but also as an opportunity to empathy, understanding, and cooperation. This essay tries to raise some questions and it should be followed by the formulation of hypotheses and their testing.

Translated by the author, edited by Klára Škrobánková

\section{LITERATURE}

ARISTOTLE. Poetics: Vol. 23 of Aristotle's work. Cambridge - London : Harvard University Press - William Heinemann, 1932.

ARISTOTLE. Poetics [transl. by Richard Janko]. Indianapolis - Cambridge : Hackett Publishing Company, 1987. ISBN 0-87220-033-7.

ARONS, Wendy. Theatre Ecology / Contemporary Plays. In Theatre Journal, 2007, Vol. 64, Issue 4, pp. 565 - 582. ISSN 0192-2882.

BALME, Christopher B. Sexual Spectacles: Theatricality and the Performance of Sex in Early Encounters in the Pacific. In The Drama Review, 2000, Vol. 44, Issue 4, pp. 67 - 85. DOI 10.1162/10542040051058483.

BEAUCHAMP, Michael S. The social mysteries of the superior temporal sulcus. In Trends in Cognitive Sciences, 2015, Vol. 19, Issue 9, pp. 489 - 490. DOI 10.1016/j.tics.2015.07.002.

BERING, Jesse M. Theistic Percepts in Other Species: Can Chimpanzees Represent the Minds of Non-Natural Agents? In Journal of Cognition and Culture, 2001, Vol. 1, Issue 2, pp. 107 - 137. DOI 10.1163/156853701316931371.

BROCKETT, Oscar G. - HILDY, Franklin J. History of the Theatre. Harlow : Pearson, 2013. ISBN 978-1292025155.

CHAUNDRI, Una. "Of All Nonsensical Things": Performance and Animal Life. In PMLA, 2009, Vol. 124, Issue 2, pp. 520 - 525. ISSN 0030-8129.

${ }^{64}$ LATOUR, B. Down to Earth: Politics in the New Climatic Regime. Cambridge : Polity Press, 2018. 
COOK, Amy. Interplay: The Method and Potential of a Cognitive Scientific Approach to Theatre. In Theatre Journal, 2007, Vol. 59, Issue 4, pp. 579 - 594. ISSN 0192-2882.

DALY, Ann. Isadora Duncan's Dance Theory. In Dance Research Journal, 1994, Vol. 26, Issue 2, pp. 24 - 31. DOI 10.2307/1477914.

DAMASIO, Antonio. Descartes' Error: Emotion, Reason and the Human Brain. London : Vintage Books, 2006. ISBN 978-0099501640.

DAWKINS, Richard - WONG, Yan. The Ancestor's Tale: A Pilgrimage to the Dawn of Life. London : Weidenfeld \& Nicolson, 2017. ISBN 978-1474606455.

DERIX, Simone. Facing as "Emotional Crunch": State visits as political performances during the cold war. In German Politics \& Society, 2007, Vol. 25, Issue 2, pp. 117 - 139. ISSN 1045-0300.

DUSSEL, Enrique. Beyond Eurocentrism: The World-System and the Limits of Modernity. In JAMESON, Frederic - MIYOSHI, Masao (Eds.). The Cultures of Globalization. Durham - London : Duke University Press, 1998. ISBN 978-0-822-32169-9.

DUSSEL, Enrique. Europe, Modernity, and Eurocentrism. In Nepantla: Views from South, 2000, Vol. 1.3, 2000, pp. 465 - 475. ISSN 1529-1650.

ESTOK, Simon C. Theory from the Fringes: Animals, Ecocriticism, Shakespeare. In Mosaic: An Interdisciplinary Critical Journal, 2007, Vol. 40, Issue 1, pp. 61 - 78. ISSN 0027-1276.

FIEBACH, Joachim. Dimensions of Theatricality in Africa. In Research in African Literatures, 1999, Vol. 30, Issue 4, pp. 186 - 201. ISSN 0034-5210.

FISCHER-LICHTE, Erika. The Transformative Power of Performance: A New Aesthetics. London New York : Routledge, 2008. ISBN 978-0-415-45856-6.

FRANCIS, Sandra T. The origins of dance: The perspective of primate evolution. In Dance chronicle, 1991, Vol. 14, Issue 2 - 3, pp. 203 - 220. ISSN 0147-2526.

FREUD, Sigmund. The Unconscious [1915]. In FREUD, Anna. (Ed.). The Essentials of Psycho-analysis. London : Vintage Books, 2005. ISBN 978-0099483649.

GALLESE, Vittorio - LAKOFF, George. The Brain's Concepts: The Role of the Sensory-Motor System in Conceptual Knowledge. In Cognitive Neuropsychology, 2005, Vol. 22, Issue 3 - 4, pp. 455 - 479. DOI 10.1080/02643290442000310.

GOODALL, Jane. In the Shadow of Man. London : Phoenix, 1999. ISBN 978-0-7538-0947-1.

GOODWYN, Erik. Approaching archetypes: reconsidering innateness. In The Journal of Analytical Psychology, 2010, Vol. 55, Issue 4, pp. 502 - 521. DOI 10.1111/j.1468-5922.2010.01862.x.

GOODWYN, Erik. The Neurobiology of the Gods. New York : Routledge, 2012. ISBN 9780415673006.

GROVOGUI, Siba N. Beyond Eurocentrism and Anarchy: Memories of International Order and Institutions. New York: Palgrave, 2006. ISBN 978-1-137-08396-8.

HAECKEL, Ernst. Die Radiolarien (Rhizopoda radiaria). Berlin : Georg Reimer, 1862.

HIGHLAND, James. Transformative Katharsis: The Significance of Theophrastus' Botanical Works for Interpretations of Dramatic Catharsis. In The Journal of Aesthetics and Art Criticism, 2005, Vol. 63, Issue 2, pp. 155 - 163. DOI 10.1111/j.0021-8529.2005.00192.x.

HUGHES, Donald J. Theophrastus as Ecologist. In Environmental Review: ER, 1985, Vol. 9, Issue 4, pp. 296 - 306. ISSN 0147-2496.

HUNT, Harry T. A collective unconscious reconsidered: Jung's archetypal imagination in the light of contemporary psychology and social science. In The Journal of Analytical Psychology, 2012, Vol. 57, Issue 1, pp. 76 - 98. DOI 10.1111/j.1468-5922.2011.01952.x.

JABLONKA, Eva - RAZ, Gal. Transgenerational epigenetic inheritance: prevalence, mechanisms, and implications for the study of heredity and evolution. In The Quarterly Review of Biology, 2009, Vol. 84, No. 2, pp. 131 -176. DOI 10.1086/598822.

JAKOVLJEVIĆ, Branislav. Theater of Atrocities: Toward a Disreality Principle. In PMLA, 2009, Vol. 124, Issue 5, pp. 1813 - 1819. ISSN 0030-8129.

JOLA, Corinne - POLLICK, Frank E. - GROSBRAS, Marie-Helene. Arousal Decrease in Sleeping Beauty: Audiences' Neurophysiological Correlates to Watching a Narrative Dance 
Performance of two-and-a-half hours. In Dance Research, 2011, Vol. 29, pp. 378 - 403. DOI 10.3366/drs.2011.0025.

JUNG, Carl Gustav - FRANZ, Marie-Louis von et al. Der Mensch und seine Symbole. Olten : Walter-Verlag, 1968.

JUST, Vladimír. Teatralita politického procesu aneb „Horáková a společníci“ jako divadelní inscenace [Theatricality of political trial, or "Horáková and fellows" as a theatre performance]. In Divadelní revue, 2006, Vol. 17, Issue 1, pp. 3 - 32. ISSN 0862-5409.

KANDEL, Eric R. - SCHWARTZ, James H. - JESSELL, Thomas M. - SIEGELBAUM, Steven A. HUDSPETH, A. James. Principles of Neural Science. Fifth Edition. New York : McGraw-Hill, 2013. ISBN 978-0071390118.

KELLERMANN, Natan P. F. Epigenetic Transmission of Holocaust Trauma: Can Nightmares Be Inherited? In Israel Journal of Psychiatry and Related Sciences, 2013, Vol. 50, No. 1, pp. 33 39. ISSN 0333-7308.

KRASBERG, Ulrike. Theateranthropologische Betrachtungen zum Ekstasetanz von Frauen in Marokko. In Anthropos, 2001, Vol. 96, Issue 2, pp. 379 - 390. ISSN 0257-9774.

LATOUR, Bruno. Down to Earth: Politics in the New Climatic Regime. Cambridge : Polity Press, 2018. ISBN 978-1509530571.

LATOUR, Bruno. We Have Never Been Modern. Cambridge, MA : Harvard University Press, 1993. ISBN 0-674-94839-4.

LOVE, Glen A. Practical Ecocriticism: Literature, Biology, and the Environment. Charlottesville London : University of Virginia Press, 2003. ISBN 0-8139-2244-5.

MAHY, Caitlin E. V. - MOSES, Louis J. - PFEIFER, Jennifer H. How and where: Theory-of-mind in the brain. In Developmental Cognitive Neuroscience, 2014, Vol. 9, pp. 68 - 81. ISSN 10.1016/j. dcn.2014.01.002.

MEINECK, Peter. The Neuroscience of the Tragic Mask. In Arion: A Journal of Humanities and the Classics, 2011, Vol. 19, Issue 1, pp. 113 - 158. ISSN 0095-5809.

MCFARLAND, David. Animal Behavior: Psychobiology, Ethology and Evolution. Menlo Park: The Benjamin/Cummings Publishing Company, 1985. ISBN 978-0805367904.

MUSILOVÁ, Martina. Teatralita veřejných událostí - uvedení do problematiky [Theatricality of public events - introduction]. In Theatralia, 2014, Vol. 17, Issue 1, pp. 9 - 24. ISSN 1803-845X.

PETERSON, Michael. The Animal Apparatus: From a Theory of Animal Acting to an Ethics of Animals Act. In The Drama Review, 2007, Vol. 51, Issue 1, pp. 11 - 22. ISSN 1054-2043.

PRADIER, Jean-Marie. Animals, Angel and Performance. In Performance Research, 2000, Vol. 5 , Issue 2, pp. 11 - 22. DOI 10.1080/13528165.2000.10871726.

PREMACK, David - WOODRUFF, Guy. Does the chimpanzee have a theory of mind? In The Behavioral and Brain Sciences, 1978, Vol. 4, pp. 515 - 526. DOI 10.1017/S0140525X00076512.

PUCHNER, Martin. Performing the Open: Actors, Animals, Philosophers. In The Drama Review, 2007, Vol. 51, Issue 1, pp. 21 - 32. ISSN 1054-2043.

RICHARDS, Robert J. The Tragic Sense of Life: Ernst Haeckel and the Struggle over Evolutionary Thought. Chicago - London : The University of Chicago Press, 2008. ISBN 978-0226712161.

RIDOUT, Nicholas. Stage Fright, Animals, and Other Theatrical Problems. Cambridge : Cambridge University Press, 2009. ISBN 978-0521617567.

RIZZOLATTI, Giacomo - FADIGA, Luciano - FOGASSI, Leonardo - GALLESE, Vittorio. Resonance Behaviors and Mirror Neurons. In Archives Italiennes de Biologie, 1999, Vol. 137, pp. 85 - 100. DOI 0003-9829.

RIZZOLATTI, Giacomo - SINIGAGLIA, Corrado. Mirrors in the Brain-How Our Minds Share Actions and Emotions. Oxford: Oxford University Press, 2008. ISBN 978-3-518-26011-1.

SEBEOK, Thomas A. Prefigurements of Art. In MARAN, Timo - MARTINELLI, Dario - TUROVSKI, Aleksei. (Eds.). Readings in Zoosemiotics. Berlin - Boston : De Gryuter, 2011. ISBN 978-3-11-025343-6. 
SIKES, Alan. Theatre History, Theatrical Mimesis, and the Myth of the Abydos Passion Play. In Theatre History Studies, 2015, Vol. 34, pp. 3 - 18. DOI 10.1353/ths.2015.0027.

SINGER, Peter. Speciesism and Moral Status. In Metaphilosophy, 2009, Vol. 40, Issue 3 - 4, pp. 567 - 581. DOI 10.1111/j.1467-9973.2009.01608.x.

STEVENS, Anthony. The Two Milion-Year-Old Self. Texas : A\&M University Press, 2005. ISBN 978-1585444953.

SZYF, Moshe. Nongenetic inheritance and transgenerational epigenetics. In Trends in Molecular Medicine, 2015, Vol. 21, No. 2, pp. 134 - 144. DOI 10.1016/j.molmed.2014.12.004.

THOMPSON-SCHILL, Sharon L. - D'ESPOSITO, Mark - KAN, Irene P. Effects of Repetition and Competition on Activity in Left Prefrontal Cortex during Word Generation. In Neuron, 1999, Vol. 23, pp. 513 - 522. DOI 10.1016/s0896-6273(00)80804-1.

TRENCH, W. F. The place of katharsis in Aristotle's aesthetics. In Hermathena, 1938, Vol. 26, Issue 51, pp. 125-126. ISSN 0018-0750.

TSUJII, Takeo - MASUDA, Sayako - AKIYAMA, Takekazu - WATANABE, Shigeru. The role of inferior frontal cortex in belief-bias reasoning: an rTMS study. In Neuropsychologia, 2010, Vol. 48, Issue 7, pp. 2005-2008. DOI 10.1016/j.neuropsychologia.2010.03.021.

UMILTÀ Maria Alessandra - KOHLER, Erwin - GALLESE, Vittorio - FOGASSI, Leonardo FADIGA, Luciano - KEYSERS, Christian - RIZZOLATTI, Giacomo. I Know What You Are Doing: A Neurophysiological Study. In Neuron, 2001, Vol. 31, Issue 1, pp. 155 - 165. DOI 10.1016/S0896-6273(01)00337-3.

UNGERER, Judy A. - ZELAZO, Philip R. - KEARSLEY, Richard B. - O'LEARY Kathleen. Developmental Changes in the Representation of Objects in Symbolic Play from 18 to 34 Months of Age. In Child Development, 1981, Vol. 52, pp. 186 - 195. DOI 10.2307/1129229.

VILLA, Dana R. Politics, Philosophy, Terror: Essays on the Thought of Hannah Arendt. Princeton : Princeton University Press, 1999. ISBN 978-0691009353.

WAAL, Frans de. The Age of Empathy: Nature's Lessons for a Kinder Society. New York: Three Rivers Press, 2009. ISBN 978-0-307-40777-1.

WEBER, Samuel. Theatricality as Medium. New York : Fordham University, 2004. ISBN 9780823224166.

YAMAZAKI, Yumiko - YOKOCHI, Hiroko - TANAKA, Michio - OKANOYA, Kazuo \& IRIKI, Atsushi. Potential role of monkey inferior parietal neurons coding action semantic equivalences as precursors of parts of speech. In Social Neuroscience, 2010, Vol. 5, Issue 1, pp. 105 - 117. DOI 10.1080/17470910802625306.

Jan Motal

Divadelní fakulta Janáčkovy akademie múzických umění

Mozartova 1

66215 Brno

Czech Republic

E-mail: motal@jamu.cz 